PROBLEMS

OF EDUCATION

IN THE $21^{\text {st }}$ CENTURY

Volume 50, 2012

\section{DIGITAL TEACHING AND LEARNING CONTENT IN NATURAL SCIENCE EDUCATION: A CASE STUDY}

\author{
Vincentas Lamanauskas, Violeta Šlekienè, Renata Bilbokaitè, \\ Loreta Ragulienè \\ University of Siauliai, Lithuania \\ E-mail: v.lamanauskas@ef.su.It, violeta@fm.su.It, renata.bilbokaite@inbox.It, \\ loretar@gmail.com
}

\begin{abstract}
Teaching/learning technologies in comprehensive schools are rapidly changing. Increasing amount of information, growing pupils' learning load raises the need to search for new, more effective teaching/ learning methods. For a long time it has been thought, that it is an object of classical pedagogy and further research works are not urgent. However, in the process of rapid development of ICT, traditional pedagogy conception also inevitably changes. So-called "classical pedagogy" shifts to "online pedagogy". An adjacent educational trend - a "shift from teaching to learning" is also related with this shift. New computer aids for increasing lesson content interactivity are being created in Lithuanian context. In the cooperation of a publishing house, teachers and scientists, a computer aid for the 5th-6th formers " biology lessons, was created. Therefore, a complex pedagogical evaluation research was carried out between January and April, 2011. 20 teachers participated in the digital content testing, who totally gave 577 lessons. In the lessons a) an interactive board (IL) was used, and a lesson content was prepared by Power Point (PPT) slide show or Active Inspire (AcIns) programme; b) projector (S), and a lesson content - by PPT or AcIns. The results, obtained on the basis of qualitative analysis, are presented in this article. It is thought, that the results of this research would contribute to implementation of computer technologies in other countries as well. Research results show, that digital teaching/learning content together with arranged lesson scenarios for the realization of the latter is undoubtedly, an innovative phenomenon in the educational practice.

It is necessary to assess the context of the country, to accomplish representative evaluations in the population of Lithuanian students and teachers.
\end{abstract}

Key words: digital content, qualitative analysis, natural science education, teaching and learning.

\title{
Introduction
}

One of the main aims of modern school is to form conditions for the teaching content to be perceivable and learnable. One of such formats is digital teaching content. To create digital teaching content and to develop modern teaching and learning services is one of the current Lithuanian education strategies. However, for effective realization of such strategy, it is necessary to know the main educational digital teaching/learning content usage peculiarities in educational process, under what conditions digital content can be effectively used and so on. On the other hand, it is perhaps not purposeful to move all teaching/learning content into digital surroundings. Thus, how to find a proper balance between traditional and digital teaching content?

Various research works carried out in foreign countries prove the effectiveness of digital teaching content. It is asserted, that digital teaching content (DTC) develops the abilities of corporation (Bennett, Sandore, Miller, 2001), strengthens motivation, being interested in 
general, develops thinking abilities (Miyata, Ishigami, 2007). Japanese researchers accentuate, that such format suits well in lower comprehensive school classes (Murai, Nakagawa, Kobayashi, Iwasaki, Matsuno, Iijima, 2009), and in general, usage of digital teaching content in teaching/learning process together with other technologies strengthens and deepens learners' understanding (Dani, Koenig, 2008).

The essential idea is - only digital teaching/learning objects do not satisfy consumers' hopes. The essential question is, what relation is between traditional teaching content tasks (published textbooks) and digital content. Should digital content replace traditional textbooks? Does digital content make teaching/learning process more effective and helps to achieve better results? How will teaching/ learning quality change using digital textbooks? and so on. In any case, the answers based on objective data are necessary and this creates new research area.

\section{Digital Teaching and Learning in Lithuania: the Current State}

In the Educational content renewal strategy implementation programme (2007-2012) it was foreseen, that it is important to create digital teaching content and to develop modern teaching and learning services (Common education..., 2006). However, this is not sufficient. Information communication technology integration into educational process can't be an end in itself, a priori claiming that it will be effective on its own. Parallelly, it is necessary to form digital teaching/learning infrastructure, to improve programmatic and technological school supply (Nekrašaitè, Petkus, 2009).

In 2005-2008 Lithuania participated in „eContentplus“ programme (European Parliament and Council direction No 456/2005/EB (OL L 79, 20053 24, p. 1). Programme has been running for four years, and its whole $149 \mathrm{mln}$. EUR budget was alloted to projects, researches and administrating (expenses connected with the proposal evaluation organisation and project reviews). Implementing the programme, it was sought at the Community level to make information creation and its spread easier in society important spheres and in this way to ensure, that digital content would be easier accessible, more convenient and more suitable to use in Europe. Programme „eContentplus" has been carried out annually, publishing invitations to submit proposals. For financing 67 projects, in which directly participated more than 800 European organizations, totally was alloted 146,9 mln. EUR. Implementing the project MELT, European learning resources for schools exchange portal (lreforschools. eun.org) was created, in which one can find educational resources and valuable material accessible to everybody, provided from more than 130000 different countries and providers (including 17 education ministries). During the project ASPECT (This project is funded under the eContentplus programme a multiannual Community programme to make digital content in Europe eContentplus more accessible, usable and exploitable) digital teaching/learning objects were created in Lithuania.

○ Nature and Man http: //mkp.emokykla.lt/gamta5-6/(1179)

- Learning Objects http://mkp.emokykla.lt/imo/

National learning object repository: $\mathrm{http}: / /$ lom.emokykla.lt was created in Lithuania for finding digital teaching/learning aids and teaching/learning objects and for doing repository exchange.

Over the last few years different internet sites devoted to digital teaching content and methodological material appeared in Lithuania.

- Centrally bought digital recourses (digital teaching/learning aids or teaching/learning objects): http://portalas.emokykla.lt/Puslapiai/KompiuterinesMokymoPriemones.aspx

- Distant teaching courses: http://vma.emokykla.lt/moodle;

- Moodle environment distant course copies (198): http://vma.emokykla.lt/licencija.html 
PROBLEMS

OF EDUCATION

IN THE $21^{\text {st }}$ CENTURY

Volume 50, 2012

- Recourses at e-school:

http://www.emokykla.lt/lt.php/istekliai/117?new_search $=1$

- Methodological works:

http://metodika.emokykla.lt

At present, digital teaching/learning aids and textbooks' conception, their demand, quality are widely discussed topics in Lithuania. Not only digital teaching/learning aid creators, Lithuanian Republic Ministry of science and education, Education development centre, higher school representatives, but also „Baltos lankos“, „TEV“, „Šviesa“ publishing houses (http:// portalas.emokykla.lt/naujienos/Puslapiai/Naujiena4318.aspx) participate in the discussions.

Since 2009 Publishing house TEV moved all its publishing textbooks to virtual space internet site www.vadoveliai.lt. Pupils, for symbolic licence fee, can download and install TEV published mathematics, information technology, economics textbooks into their computer.

„Šviesa“ publishing house prepared digital teaching/learning content to some textbook sets. These are different subject tasks for active learning, using interactive board during the lesson. Interactive slide task comprises 8-12 slides for making pupils interested, for topic actualization, for new material presentation, for knowledge and ability consolidation, for evaluation and self-evaluation. Task usage scenarios are prepared - methodological support for the teacher, preparing for the lesson and during the lesson. In the scenario the teacher is presented with the general information about the lesson (topic, aids, students' achievements, learning tasks) and the description of every slide usage during the lesson - methodological and technological recommendations (what activities, tasks to perform on the interactive board and how). The teacher can correct the prepared digital content according to his and his class pupils demands: to make learning tasks more concrete, to change or supplement prepared material by available recourses (documents, images, texts, video material, created tasks, references and other).

Digital teaching/learning content is prepared for these subject textbook sets:

- For the I-st form - Integrated Lithuanian language, World cognition, Mathematics („Bean“, „Acorn“" „Nut“ I-st form);

- For the V-th and VI-th forms - Nature and man (,In scientists“ footsteps“ V-th and VI-th forms);

- For the V-th and IX-th forms Mathematics (,Formula“ V-th form, „Mathematics“ IXth form);

- For the IX-th form - Biology („Biology“ IX-th form). Digital teaching/learning content will be continuously prepared for the other subjects as well in different forms.

\section{Defining the Problem}

Digital teaching/learning content, as research works carried out in other countries show, can be an effective means in the teaching/learning process. Besides, it is necessary to develop digital literacy of the youth. In the information society it becomes a priority direction in education. Lithuania lacks of such research works. Quite often teachers practitioners "are experimenting" in a very limited area and restrict themselves to only individual digital content component creation, e.g., of various computer teaching programmes. Exhaustive, experimental research works of a wider amount are necessary, allowing to basically assess DTC importance in teaching/learning practice. 


\section{Object, Aim of the Research}

Theoretical framework. This article is based on cognitive constructivism theory (Fosnot, 1996; Cakir, 2008; Nezvalova, 2009), giving the meaning of importance to interactive aid usage in educational process. With the help of modern and qualitative computer programmes, the information is presented to the pupils in the form of double code (visual and verbal), therefore it increases the opportunities for better mastering of the information and recalling it. Double coded information helps to more assimilate and accomodate natural science knowledge with the help of mental models, therefore the learners easier and faster conceive the content of the lesson and the teacher organizes pupils' activities more effectively. Referring to cognitive constructivism ideas, it is thought, that a probationary aid will help to create conditions, in the context of which the pupils will be able to construct their individual knowledge more effectively.

The object of this complex research is the digital content of digital presentations and lesson scenarios applied for "Nature and man" subject lessons. Digital presentations and lesson scenarios are arranged according to the content of the textbook "In scientists" footsteps 5".

Seeking the created aid to be effective in practice, it is necessary to check its effectiveness, making sure, that it can be used and to strive for better results knowing, that using it, favourable conditions are created for cognitive knowledge acquisition. The main aim is to evaluate the arranged digital teaching/learning content. The concept "content" is understood as the wholeness of all presented information and tasks, related with a concrete topic, applied for one lesson activities. The content was evaluated referring to qualitative analysis of teachers' answers to open questions and focus groups' result analysis.

\section{Research Methodology}

The presented research was carried out implementing the project "Aurora". The start of the project is August, 2010. The end of the project is May, 2011. During this period the group of researchers accomplished various researches, seeking to evaluate digital teaching content effectiveness and its usage possibilities in the $5^{\text {th }}$ forms of comprehensive schools. The main aim of the research is to create digital content and its application scenarios for "Nature and man" subject lessons, using the material of the textbook "In scientists' footsteps 5". Therefore, a complex pedagogical evaluation research was carried out between January and April, 2011. 20 teachers participated in the digital content testing, who totally gave 577 lessons. Digital lesson content with scenarios for every lesson was successfully arranged and presented in three formats: Active Inspire, PowerPoint and PDF. The arranged material was stored in the internet, CD, USB memory sticks. In Figure 1 digital content slide examples on the subject "About teeth and chewing gum" are presented. 
PROBLEMS

OF EDUCATION

IN THE $21^{\text {st }}$ CENTURY

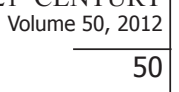
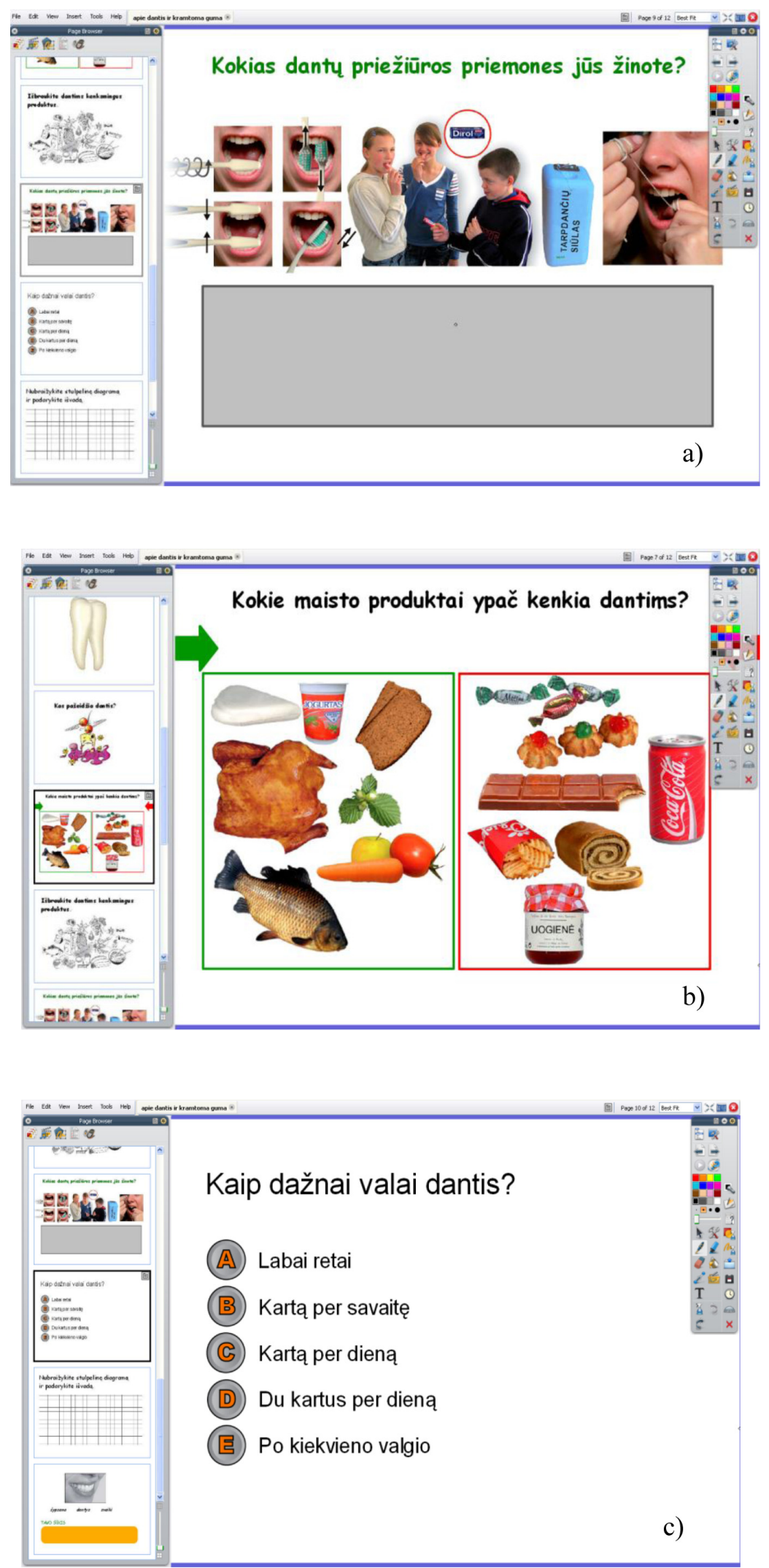

Figure 1: Digital content fragments on the subject $(a, b, c)$. 
These slides are prepared in the Active Inspire format. On the right interactive tools are seen, with the help of which the pupils can accomplish different tasks. For example, to write, what dental care aids they know (Figure 1a), to distribute the products according to their effect on teeth (Figure 1b) or, using poll buttons, to answer, how often they clean teeth (Figure 1c.). Pupils' answer data are processed immediately and the obtained results can be shown graphically on another slide.

The selected group of 20 experienced teachers successfully tried the arranged digital teaching content in educational practice. The team of researchers gathered an exhaustive amount of data. Data were analysed and generalised. The first quantitative research results were published earlier (Lamanauskas, Šlekienė, Ragulienè, Bilbokaitè, 2011).

For the evaluation of digital teaching/learning content, every teacher was given to fill in evaluation sheet of every lesson and they were asked to describe in brief their experience/ experiences/ impression, realizing the scenario of every lesson. Two open questions (the respondents were asked to point out the most positive and the most negative aspects of a concrete lesson) were given to the respondents. From the respondents' answers a qualitative data analysis was made. There were defined sub-categories and categories from the meaningful propositions.

\section{Research Results}

Having carried out qualitative analysis of the research results, one can claim, that teachers, in fact, positively evaluate digital teaching/learning content and its usage possibilities in educational practice. All teachers, having participated in the research, would like to give lessons with the arranged digital teaching/learning content in future as well. It has been stated, that the usage of digital teaching/learning content makes the lesson more effective regardless the lesson topic (makes it more interesting, more diverse, more attractive), develops pupils ${ }^{6}$ cognitive and psychosocial abilities, strengthens learning motivation, makes teaching/learning process itself more active. Besides, the usage of digital teaching/learning process perfoms a supplementary role in educational process, using various ICT, as for example,interactive boards, manifold projectors and other. The teachers positively evaluated poll button usage, which especially made the lesson livelier, involving the pupils to express their opinion, discuss. The teachers expressed their wish to work with poll buttons in future too. Therefore, it would be necessary to prepare more tasks for the work with them and to suggest, that schools acquired them.

Digital teaching aid was analysed in positive and negative aspects. Almost in all the lessons the pedagogues emphasized positive aspects, which matched general characteristic identification categories. Negative aspect was identified mostly due to technical obstacles, which limited effective usage of the aid in educational process. They were mentioned only for concrete slides or for a few lessons.

Digital teaching/learning content aid's advantages in educational process were systemized and divided into 6 categories: motivation, aid suitability, feedback, knowledge acquisition, activeness and easier work (Figure 2). 


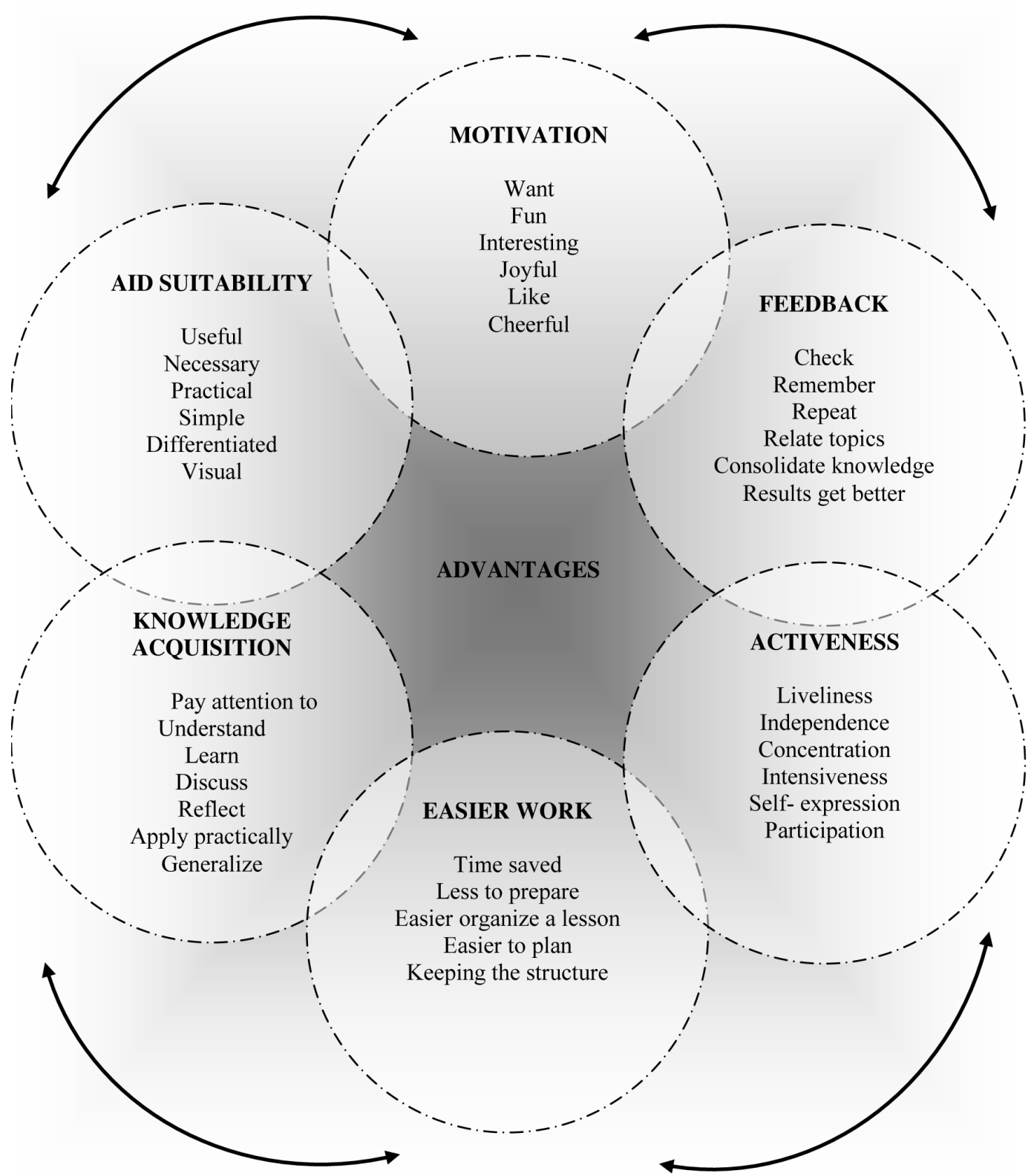

Figure 2: Digital teaching/learning aid's advantages in educational process.

Motivation. The respondents state, that the students liked the aid, asserting, that this was expressed by a bigger joy - agreement, verbalized need to repeat, more active hand raising, bigger questioning and answering. The pupils' internal satisfaction with the aid also showed, that all learners, having a wider interest in teaching content and further tasks, became involved into activities. The pupils used to assert, that they „like“, „interesting“, ,joyful“, which reveals aid's suitability to encourage pupils' learning motivation.

Feedback. The research results reveal, that teaching aid can ensure more effective 
feedback. Digital content prepared in a proper way helped the pupils to revise earlier learned lesson material and to relate it with the new information. It is also accentuated, that during learning process the learners, recalling past topics or its elements, had deeper consolidation of the learnt material, which conditioned wider learning perspectives of further topics. Referring to pedagogues' opinion, they could quicker understand - what is clear to pupils, what needs additional analysis, therefore learning was running more effectively, though less efforts were used than usual.

Pupils' activeness. Teachers say, that digital content encourages pupils' activeness, which reveals itself in liveliness, wish to express one's opinion loudly, more to discuss and share one's experience, related with the topic of the lesson. The pupils are concentrated, more attentive, more willingly work in groups, cooperate with their counterparts, listen to the teacher and answer the questions, which can be named as intensive learning in the changed educational environment. A livelier pupils' discussion determined a wider lesson content exposure, more diverse attitude expression, without causing behavioural problems in the lessons. Pupils" activeness, in teachers' opinion, was also determined by the fact that they discerned practical use of the topic, knowledge realization in an ordinary life.

Knowledge acquisition. Digital learning content helped the pupils to better acquire lesson material, because they understood more complex concepts easier, they faster remembered them. The learners strengthened their knowledge by discussions, practical works, generalising and reflecting the lesson, discerning practical theoretical knowledge use. Using digital content for learning exposed the learners ${ }^{\text {‘ }}$ abilities to independently understand and perform tasks better, to make conclusions themselves and generalize the learnt information.

Easier teacher's work. Pedagogues state, that it was easier for them to prepare for the lessons at home, they saved a lot of lessons, because the information in the aid is suitably presented - plenty of needful illustrations, therefore it is not necessary to additionally search for visualisations on the internet. Smaller time expenditure was fixed in the lessons - teachers faster explained the topic of the lesson, looked over the previous topics wider and it was easier to perform practical works, without deviating from the plan, it was clearer to keep structure, organize pupils' work.

Aid suitability. Referring to pedagogues' opinion, digital aid was useful and necessary for them. It made the work easier, it was clear and simple for pupils, tasks were presented practically, therefore they were meaningful in practical sense, theoretical information was illustrated by visual examples, and tasks were differentiated, therefore all the pupils involved themselves into activities.

Negative aspects are also discerned in the aids: technical obstacles, shortage of differentiated tasks, a small illustration bank, there is a lack of information from additional recourses in the teaching content. Regarding negative aspects, the teachers accentuated technical digital teaching/learning aid's difficulties: in some slides the text's font size was not proper - too small or too big, the slides didn't open in some lessons, because there was too much of the material stored, complicated navigation. Pedagogues remarked, that there were lessons, during which the pupils were not able to perform all the tasks, because they were short of time or because of technical obstacles the tasks were read later than planned, therefore a lot of time was wasted. The teachers made comments concerning concrete slides as well - it was sought that the tasks were more concrete, the text much clearer, vizualization more reflecting complicated and invisible things, which would supplement pupils ${ }^{6}$ learning material. Besides, there was a shortage of additional different level tasks, that the teachers could differentiate the teaching, i.e. work with different ability pupils. They wish that digital learning content contained the material not only from textbooks and workbooks, but from other sources as well. The teachers willingly use illustration bank, however it is insufficient. For some topics illustration shortage is felt. 
PROBLEMS

OF EDUCATION

IN THE $21^{\text {st }}$ CENTURY

Volume 50, 2012

\section{Conclusions}

Digital teaching/learning content is mutually useful in the educational process - for pupils it is easier to understand and master the material, easier to discuss things, work in groups and independently, it is simpler to discern practical theory applicability in life and to learn complicated information more firmly; for pedagogues it is easier to prepare for the lesson, to save time, not to deviate from the planned structure and procedure in the lessons, pupils are easier controlled, their work is organized, faster and more effectively feedback is obtained, pupils' more active interest in learning content is noticed, which reveals itself as intensive work in the lessons.

Digital learning aid is marked as necessary, in spite of sometimes experienced technical difficulties, too many complicated tasks, font size, or individual meant for representation remarks on concrete topic slides.

It has been stated, that DTC usage:

o makes the lesson more effective, regardless of the lesson topic: it makes it more interesting, diverse, attractive;

o makes a great influence on the pupils: makes them interested, makes the lesson understanding easier, helps to concentrate pupils' attention and so on;

o develops pupils' cognitive and psychosocial abilities, strengthens teaching motivation, makes teaching/learning process active.

\section{Note}

This is a revised and expanded version of an international scientific symposium paper in Problems of Education in the 21st Century. The paper was recommended for republication by the symposium scientific committee.

The reference for the Symposium version is:

Lamanauskas, V., Šlekienè, V., Bilbokaitė, R., Ragulienè, L. (2012). Digital Teaching and Learning Content in Natural Science Education: A Case Study. In. Science \& Technology Education for Development, Citizenship and Social Justice (International XV IOSTE Symposium Proceedings Online, Hammamet, Tunisia, October 28 November 3, 2012). La Medina - Yasmine Hammamet.

\section{References}

Bennett, N., Sandore, B., \& Miller, P. (2001). Enabling Real Collaboration Through Virtual Tools: The Teaching with Digital Content Consortium Experience. Presentation at MCN/CIMI 2001, Real Life: Virtual Experiences: New Connections for Museum Visitors.

Cakir, M. (2008). Constructivist Approaches to Learning in Science and Their Implications for Science Pedagogy: A Literature Review. International Journal of Environmental \& Science Education, 3 (4), 193-206.

Dani, D. E., \& Koenig, K. M. (2008). Technology and Reform-Based Science Education. Theory into Practice, 47 (3), 204-211.

Fosnot, C. T., ed. (1996). Constructivism: Theory, perspectives, and practice. New York, NY: Teachers College Press.

Lamanauskas, V., Šlekienè, V., Ragulienè, L., \& Bilbokaite, R. (2011). Digital Teaching and Learning Content in Natural Science Education: Educational Usefulness Evaluation. Problems of Education in the 21st Century (Information \& Communication Technology in Natural Science Education $-2011), 37,70-82$. 
Vincentas LAMANAUSKAS, Violeta ŠLEKIENĖ, Renata BILBOKAITĖ, Loreta RAGULIENĖ. Digital Teaching and Learning Content in Natural Science Education: a Case Study

Miyata, H., \& Ishigami, M. (2007). Effects of using digital contents designed for PDA as a teaching aid in an observational learning of planktons for fieldworks on a ship. Advanced Technology for Learning, 4 (3), 146-153.

Murai, M., Nakagawa, H., Kobayashi, Y., Iwasaki, K., Matsuno, N., \& Iijima, K. (2009). The Digital Teaching Materials are Utilized for the Science Education at a Japanese Elementary School. In G. Siemens \& C. Fulford (Eds.), Proceedings of World Conference on Educational Multimedia, Hypermedia and Telecommunications 2009 (pp. 73-78). Chesapeake, VA: AACE.

Nekrašaitė, K., Petkus, T. (2009). Informacinių technologijų naudojimas mokymui. Informacijos mokslai, $50,112-116$.

Nezvalova, D. (2009). Assessing Science for Understanding - Constructivist Approach. Olomouc.

Advised by Laima Railiene, University of Siauliai, Lithuania

Received: September 10, 2012

Accepted: November 12, 2012

PROBLEMS

OF EDUCATION

IN THE $21^{\text {st }}$ CENTURY

Volume 50, 2012

(2) Accepted: November 12,2012

\begin{tabular}{|c|c|}
\hline Vincentas Lamanauskas & $\begin{array}{l}\text { Professor, Natural Science Education Research Centre, University of Siauliai, } \\
\text { 25-119 P.Višinskio Street, LT- } 76351 \text {, Siauliai, Lithuania. } \\
\text { Phone: + } 37068795668 \text {. } \\
\text { E-mail: lamanauskas@projektas.It } \\
\text { Website: http://www.lamanauskas.projektas.It }\end{array}$ \\
\hline Violeta Šlekienè & $\begin{array}{l}\text { Associate Professor, Head of Department of Physics, Faculty of Natural Sci- } \\
\text { ences, University of Šiauliai, } 19 \text { P. Visinskio Street, LT- } 77156 \text { Siauliai, Lithuania. } \\
\text { Phone: }+37041595721 . \\
\text { E-mail: fk@fm.su.lt } \\
\text { Website: http://www.su.lt/ This e-mail address is being protected from spambots } \\
\text { You need JavaScript enabled to view it }\end{array}$ \\
\hline Renata Bilbokaitė & $\begin{array}{l}\text { PhD., Researcher at the Natural Science Education Research Centre, University } \\
\text { of Siauliai, } 19 \text { P. Visinskio Street, LT-77156 Siauliai, Lithuania. } \\
\text { E-mail: renata.bilbokaite@inbox.It }\end{array}$ \\
\hline Loreta Raguliené & $\begin{array}{l}\text { Associate Professor, Lecturer of Department of Physics, Faculty of Natural Sci- } \\
\text { ences, University of Šiauliai, } 19 \text { P. Visinskio Street, LT-77156 Siauliai, Lithuania. } \\
\text { Phone: }+37041595721 . \\
\text { E-mail: fk@fm.su.lt } \\
\text { Website: http://www.su.lt/ }\end{array}$ \\
\hline
\end{tabular}

